\title{
OS CERCAMENTOS MORTAIS EM RONDÔNIA
}

\section{The Mortal Enclosures in Rondônia}

\author{
Prof $^{\mathrm{a}}$. Dra . Helena Angélica de Mesquita \\ Universidade Federal de Goiás, Instituto de Estudos Sócio-Ambientais, Cac. \\ Av. Dr. Lamartine Pinto de Avelar, 1120, CEP: 75700-000 - Catalao, GO - Brasil
} Tel/Fax: (+55 64) 4411505 / 4411515 - helena@wgo.com.br

\section{$a a \boldsymbol{a} a a$}

\begin{abstract}
Resumo
Este texto é parte da tese de doutorado intitulada Corumbiara: o massacre dos camponeses/Rondônia, 1995, defendida em 2001, na USP, E trago este assunto a debate porque, apesar dos 10 anos de conclusão da pesquisa, a situação no Brasil e especialmente em Rondônia pouco se alterou, a violência e a impunidade ainda estão presentes onde estão as cercas do latifúndio. Em Corumbiara, os camponeses é que foram punidos e o Júri Popular apenas confirmou a condenação que lhes fora impingida desde que sonharam com a posse da terra e ousaram ir à luta pra concretizar aquele sonho. São séculos de luta pela terra no Brasil no país do latufúndio. A metodologia básica foi fazer um paralelo entre as fontes oficiais (processo crime Caso Corumbiara) e a História a mim contada pelos sobreviventes do massacre daquele massacre.
\end{abstract}

Palavras chave: campesinato, luta pela terra, processo crime, latifúndio, Júri Popular

\begin{abstract}
This text is part of the doctorate thesis of intitled Corumbiara: the slaughter of the peasants/Rondônia, 1995, defended in 2001, the USP, and I bring this subject the discussion because, although the 10 years of conclusion of the research, the situation in Brazil and especially in Rondônia little one got excited, the violence and impunity still is gifts where you surround they are them of the large state. In Corumbiara, the peasants are that they had been punished and the Popular Jury only confirmed the conviction that them is imposed since that they had dreamed of the ownership of the land and had dared to go to the fight pra to materialize that dream. They are centuries of fight for the land in Brazil in the country of the agricultural estate. The basic methodology was to make a parallel between the official sources (process crime Corumbiara Case) and History counted me for the survivors of the slaughter of that slaughter.
\end{abstract}

Keyword: peasantry, fight for the land, process crime, agricultural estate, Popular Jury

\section{Resumen}

Este texto es parte de la tesis de doctorado titulada Corumbiara: la masacre de los campesinos/Rondônia, 1995, defendida en 2001, en la USP, Y traigo este asunto para el debate porque, a pesar de los 10 años de conclusión de la investigación, la situación en el Brasil y especialmente en Rondônia poco se alteró, la violencia y la impunidad aún están presentes donde están las cercas del latifundio. En Corumbiara, los campesinos fueron punidos y el Júri Popular apenas confirmó la condenación que les fuera impugnada desde que soñaron con la pose de la tierra y osaron ir a la lucha para concretizar aquel sueño. Son siglos de lucha por la tierra en el Brasil en el país de los latifundios. La metodología básica fue hacer un paralelo entre las fuentes oficiales (proceso crimen Caso Corumbiara) y la Historia a mí contada por los sobrevivientes de la masacre, de aquella masacre.

Palabras Clave: campesinado, lucha por la tierra, proceso crimen, latifundio, Júri Popular.

\section{$a \mathbf{C a a}_{a}$}




\section{INTRODUÇÃO}

A ocupação capitalista da terra, no Brasil, tem sido marcada pela violência. São séculos de políticas que legitimam o latifúndio e tudo o que ele representa, gerando concentração de terras e de rendas e a consequente exclusão de considerável massa de trabalhadores da possibilidade de acesso a terra, ao trabalho e á cidadania. São as capitanias hereditárias, as sesmarias e quando se insinuava alguma alteração veio a Lei de Terras de 1850. Chegamos á República dos latifundiários, das oligarquias agrárias já antecipadamente legitimadas pela Lei 1850. Mas, os excluídos reagem de diversas formas e em vários campos de lutas.

São inúmeros conflitos que são transformados em massacres contra camponeses, meninos, índios, negros, imigrantes e pobres em gera. Tem sido brutal a luta dos negros que chegaram ao Brasil na condição de escravos, ou seja, marginalizados à priori e constituíram a força de trabalho que moveu a Colônia, mas como trabalhador que era, ao mesmo tempo, mercadoria. Se em 1888 a Lei Áurea, colocou fim a escravidão como instituição, não foi permitido aos negros chegar a cidadãos, pois o que lhe garantiria tal possibilidade seria o acesso à terra. Qual terra, neste imenso território?

A contradição se estabeleceu quando, para se reproduzir, o capital passou a utilizar a propriedade privada da terra e a renda que ela podia proporcionar. A mão-de-obra, por sua vez, precisava também corresponder à nova ordem mundial de expansão de consumo e de produção de matérias-primas para as nações em processo de industrialização, especialmente para a nova potência que emergia

A República brasileira já nasceu sob o signo do latifúndio e da “ordem e progresso", inserindo o país no contexto do liberalismo. Mas a República, que foi um arranjo entre latifundiários e militares, foi "inaugurada" por um dos maiores movimentos de resistência camponesa, a Guerra de Canudos. Canudos foi combatido pela Igreja, pelos coronéis/latifundiários e pelo Estado positivista. A ordem em Canudos era construir uma comunidade solidária e o progresso certamente seria o bem estar de todos. Canudos era uma comunidade de lutadores que se negou a sucumbir ao latifúndio, por isso foi destruída até as cinzas.

Assim caminha o nosso país. Cada conjuntura tem servido para legitimar o latifúndio. Os coronéis não "apearam" do poder com o movimento de 1930. As oligarquias agrárias, fizeram alianças, acordos, conchavos e se locupletam até hoje, travestidos de "ruralistas". Na segunda metade do século XX o país faz sua opção pelo processo conservador de modernização da agricultura, reafirmando a subserviência ao capital internacional e se transforma em um grande produtor/exportador de commodities. É o colonialismo se impondo a custa da exploração sobre a terra e o sobre trabalho até limites extremos. E as fronteiras econômicas são transformadas em fronteiras geopolíticas. É o caso de Rondônia que abordo neste artigo.

A ocupação capitalista de Rondônia começou no final do século XIX quando chegou ao território um primeiro contingente de trabalhadores para a extração da borracha, o que demandou a construção da estrada de ferro Madeira-Mamoré, iniciada em 1907 e concluída em 1912, cujos extremos eram as cidades de Porto Velho e Guajará-Mirim, que foram as duas únicas cidades da região por muitos anos. A Madeira-Mamoré, apesar de ter um custo imenso em vidas humanas e em recursos financeiros, foi rapidamente abandonada e hoje restam as belas pontes com estruturas magníficas. Somente na década de (19)50, com a descoberta da cassiterita e com os garimpos de ouro, e na década de (19)70, com o processo de colonização dirigida, incentivada pelo governo, Rondônia conheceu um processo de ocupação capitalista efetiva, baseada na agropecuária, especialmente nos cultivos de cacau, café, e capim, transformando a estrutura produtiva e atraindo um fluxo migratório sem precedentes. Segundo informações do Centro de Triagem de Migrantes/RO, a maioria destas pessoas eram agricultores do Centro-Sul, expulsos de suas regiões pela modernização da agricultura que, aliada às políticas agrícolas e agrárias, geraram concentração fundiária e redução dos empregos no campo. Os projetos de colonização dirigida promoveu uma diferenciação brutal entre as diversas categorias de migrantes. Os mais pobres acabaram "sobrando" destes 
projetos e estão, desde 1980, em luta por terra e redesenhando o "xadrez das terras" O atual estado de Rondônia chamou-se Território de Guaporé de 1943 a 1965 quando passou a denominar-se Território de Rondônia e em 1981 tornou-se Estado da Federação. O grande fluxo migratório para Rondônia foi, no período (19)70 e 80, composto principalmente por trabalhadores sem-terra, de desempregados e subempregados rurais e urbanos oriundos de várias regiões do país. As cidades aumentaram tanto em número como em problemas típicos de aglomerados sem a menor estrutura no que se refere a equipamentos de saneamento básico. Em Vilhena, o "Portal da Amazônia", acabam ficando aqueles que para lá se dirigiram sem ter alguém como referência em qualquer lugar do estado. São pobres que ficam cada vez mais pobres. Os projetos de assentamentos coordenados pelo governo seguem o eixo formado pela rodovia BR-364. O INCRA atribuiu aos camponeses migrantes a responsabilidade pelos transtornos criados pelo modo de colonização que privilegiava quem tinha maior poder aquisitivo e influência política, quem estava à procura de novas oportunidades de negócios, especialmente acumular terras para especulação e para a extração de madeira e minérios. Em Rondônia, as políticas agrárias e agrícolas foram implantadas de cima para baixo e o Estado não forneceu apoio aos pequenos produtores que se viram contrapostos aos mecanismos de mercado que tendem a expropriá-los. Então o processo de apropriação de terras é marcado pela ação dos grandes fazendeiros e grileiros que conseguem cadastrar "suas" glebas junto ao INCRA, restringindo as terras disponíveis. Em Rondônia, a face da colonização dirigida revelou uma forma de aumentar a acumulação e o papel do migrante ou posseiro acabou sendo de valorizar a terra e assim torná-la cada vez mais inacessível a eles mesmos. O processo não foi e não é pacífico. Os expropriados estão sempre se organizando e ocupando as áreas improdutivas. E o latifúndio se impõe e as reações dos pobres são reprimidas ferozmente com a conivência do Estado. Conflitos por terras se espalham como espalham as cercas dos latifúndios. É o que aconteceu na fazenda Santa Elina, no município de Corumbiara, em 1995. Uma área improdutiva de cerca de vinte mil hectares, teve uma pequena parte ocupada por, aproximadamente, seiscentas famílias, estabelecendo um conflito. Aquele acampamento de sem terra foi massacrado por policiais, jagunços e guaxebas, comandados por fazendeiros $\mathrm{O}$ massacre de Corumbiara é uma prova que o latifúndio ainda governa Rondônia. E o Júri Popular, em 2000, no qual foram julgados os "envolvidos" no "Caso Corumbiara" garantiu a impunidade de fazendeiros, policiais e políticos, pois todo o processo foi construído para criminalizar os sem terra.

Os índios estão há quinhentos anos lutando, fugindo, morrendo e resistindo numa guerra contra o capital, representado por jesuítas, por senhores de engenho e, hoje por grileiros, madeireiros, latifundiários, todos contaram/contam com a conivência do Estado.

Assim como tem sido a luta dos negros que chegaram ao Brasil na condição de escravos, ou seja, marginalizados à priori e constituíram a força de trabalho que moveu a Colônia, mas como trabalhador que era, ao mesmo tempo, mercadoria. Se em 1888 a Lei Áurea, colocou fim a escravidão como instituição, não foi permitido aos negros chegar a cidadãos, pois o que lhe garantiria tal possibilidade seria o acesso à terra. Qual terra, neste imenso território?

\section{A PRODUÇÃO DO ESPAÇO AGRÁRIO}

\section{Algumas Considerações Acerca do Campo Brasileiro}

Nesta sociedade pós-moderna, pós-industrial, a maioria das pessoas não consegue mais perceber o papel da agricultura - não de agronegócio - porque já se perdeu a noção do que é essencial à sobrevivência humana, o alimento, e de onde ele vem, o campo!

Para compreender tudo isso, o olhar do geógrafo deve se valer também dos olhares de estudiosos de outras áreas, para que se possa ter clareza do processo de produção e reprodução do espaço geográfico, que é o resultado da luta de classes e da correlação de forças dentro do contexto histórico. 
José de Souza Martins procura explicar a permanência e até a recriação do campesinato. Segundo ele, o próprio capitalismo mantém e cria as relações não capitalistas de produção. Percebe-se a ampliação da produção familiar combinada, ou não, dentro da contradição capitalista, por isso o campesinato e o latifúndio devem ser compreendidos dentro do capitalismo e não fora dele, conforme Oliveira ( 1986).

Importante é a abordagem acerca da lógica camponesa em relação a vários aspectos, tais como a questão da posse e propriedade, da liberdade e da segurança. Para o camponês a terra é a garantia de um meio de produção da vida e a liberdade em reação ao trabalho.

A trama da luta de classes envolve não apenas práticas, atitudes, como também a memorização do acontecer social que também faz parte do exercício do poder. Faz parte do exercício do poder ocultar a diferença, a contradição, decidindo o que deve ser lembrado e em contrapartida, o que deve ser esquecido. (VIEIRA, 1989, p. 27).

Neste texto estou propondo dialogar com as evidências e ultrapassar as aparências para compreender a realidade como expressão do exercício do poder, o poder de ocultar, de esquecer e o poder de mostrar e de não esquecer, o que seria um outro poder. Assim abordo o Massacre de Corumbiara .

O fim da escravidão como instituição, veio quase quarenta anos após a instituição do que Martins (1990) chamou de "cativeiro da terra". Os negros, que entraram no país como escravizados, o advento da República lhes foi dificultou a cidadania por falta de uma política que lhe possibilitasse o acesso a terra. Mas eles sempre lutaram por terra, assim como os imigrantes europeus que também aspiravam a terra. Este foi o caldo dos muitos conflitos que aconteceram no país.

A República brasileira já nasceu sob o signo do latifúndio e da "ordem e progresso", inserindo o país no contexto do liberalismo. Mas a República, que foi um arranjo entre os latifundiários e os militares, foi "inaugurada" por um dos maiores movimentos de resistência dos trabalhadores, a Guerra de Canudos. Canudos foi combatido pela Igreja, pelos coronéis/latifundiários e pelo Estado positivista da "ordem e progresso".

O instrumento mais específico para o avanço da modernização conservadora foi, sem dúvida, o Estatuto da Terra de 1964, cuja letra sugeria, inclusive, reforma agrária, mas cujo espírito era tão somente o de fortalecer e legitimar o poder dos empresários rurais. Esse modelo de desenvolvimento expropriou pequenos produtores, expulsou moradores e agregados e reduziu postos de trabalho no campo. Mas os excluídos sempre reagiram no campo e nas cidades, embora tal reação tenha sido negada, quando não desqualificada pelas elites.. A resistência dos trabalhadores foi evidenciada pela formação das Ligas Camponesas que marcaram o Nordeste nos anos 1950 a 1960.

Em 1964 o golpe Militar tentou golpear também a resistência dos trabalhadores, caçando, matando e "sumindo" com as lideranças em uma tentativa de destruir qualquer movimento que questionasse o regime. Os latifundiários, que apoiaram a ditadura militar desde o seu nascedouro se fortaleceram legalmente, legitimados pelo Estatuto da Terra. Conflitos por terra emergem em muitos lugares do Brasil e foram crescentes as tensões sociais, especialmente na Amazônia, relacionadas diretamente à natureza das migrações produzidas pela estrutura fundiária. Martins (1986) A "Nova República" já nasceu velha, velha e rançosa, pois a nova "arrumação" do poder continuou calcada na influência dos latifundiários.

\section{A Produção do Espaço em Rondônia}

A partir de 1970, houve a interferência direta do Estado na ocupação do território e este período pode ser dividido em duas etapas. Em Rondônia, a primeira etapa vai de 1970 a 1980 quando o INCRA definiu o que Cunha (1980) chamou de "xadrez das terras" e a outra etapa foi a partir de 1980 quando os projetos do INCRA se mostraram ineficientes pois não davam conta de resolver a questão fundiária e menos ainda a questão dos migrantes pobres, a grande maioria, que não 
conseguiram o seu grande objetivo que era entrar na terra e ficar na terra, fazendo-a produzir. Esta segunda etapa foi marcada pela ação dos Sem-Terra que se mobilizaram e forçaram o Estado a criar dezenas de Projetos de Assentamentos (PA) para abrigá-los

Todo esse processo funcionou como forte atrativo para populações pobres de diversas regiões brasileiras, mas nem todos tiveram acesso a terra, e muitos dos que conseguiram "entrar" na terra tiveram dificuldade em se manter nela.

O fluxo migratório para Rondônia foi, no período questão, composto principalmente por trabalhadores sem-terra, de desempregados e subempregados rurais e urbanos oriundos de várias regiões do país. As cidades aumentaram tanto em número como em problemas típicos de aglomerados sem a menor estrutura no que se refere a equipamentos de saneamento básico.

Em Rondônia, as políticas agrárias e agrícolas foram implantadas de cima para baixo e o Estado não forneceu apoio aos pequenos produtores que se viram contrapostos aos mecanismos de mercado que tendem a expropriá-los. Então o processo de apropriação de terras é marcado pela ação dos grandes fazendeiros e grileiros que conseguem cadastrar "suas" glebas junto ao INCRA, restringindo as terras disponíveis. Em Rondônia, a face da colonização dirigida revelou uma forma de aumentar a acumulação e o papel do migrante, posseiro ou colono acabou sendo de valorizar a terra e assim torná-la cada vez mais inacessível a eles mesmos.

O processo não foi e não é pacífico. Os expropriados estão sempre se organizando e ocupando as áreas improdutivas. As ocupações são constantes e ocorrem em grandes áreas ociosas.

São os trabalhadores sem terra, sejam eles organizados pelo Movimento dos Trabalhadores Rurais sem Terra (MST), Movimento Camponês Corumbiara (MCC), Sindicato dos Trabalhadores Rurais (STR), Federação dos Trabalhadores da Agricultura de Rondônia (FETAGRO), Centro de Triagem de Migrantes (CETREMI0, Movimento de Pequenos Agricultores (MPA), ou qualquer tipo de organização, é que estão rompendo o xadrez da terra e estão redesenhando e remodelando o espaço em Rondônia.

Analisar e compreender a produção do espaço em Rondônia é um desafio, principalmente para quem quer levar em consideração as contradições da sociedade capitalista. Até as relações sociais que se estabeleceram na região são diferentes daquelas de outras regiões do país. As relações de compadrio e amizade, por exemplo, tão conhecidas nas antigas fazendas do Centro-Sul, naquele novo espaço pouco aparecem. Isso diferencia as relações sociais, pois os que trabalham para o fazendeiro são mesmo os seus peões e, às vezes, jagunços; trabalham nas atividades inerentes à agropecuária, mas também atuam como milícia armada. O modelo de colonização adotado engendra um estado permanente de tensão. Os sem-terra, muito pobres, estão ao lado dos muito ricos. Os sem-terra sabem quem são e conhecem os seus pares e os seus inimigos. Isto, na fronteira, gera uma situação de conflito latente e, em certos momentos, estes conflitos atingem grande intensidade, como aconteceu em Corumbiara. E as perseguições atingem também aqueles que se colocam em defesa dos sem-terra: os padres, sindicalistas, advogados.

A gleba Corumbiara é hoje área de grandes propriedades. O desmatamento era a forma de reconhecimento da posse de novas áreas mas os índios e os posseiros não desmatam em grande escala, portanto, não "cumpriam" as exigências para garantir a posse. O efeito dessa política é mais intenso ao longo da rodovia BR-364. mas a região de Corumbiara não escapou dessa política. 


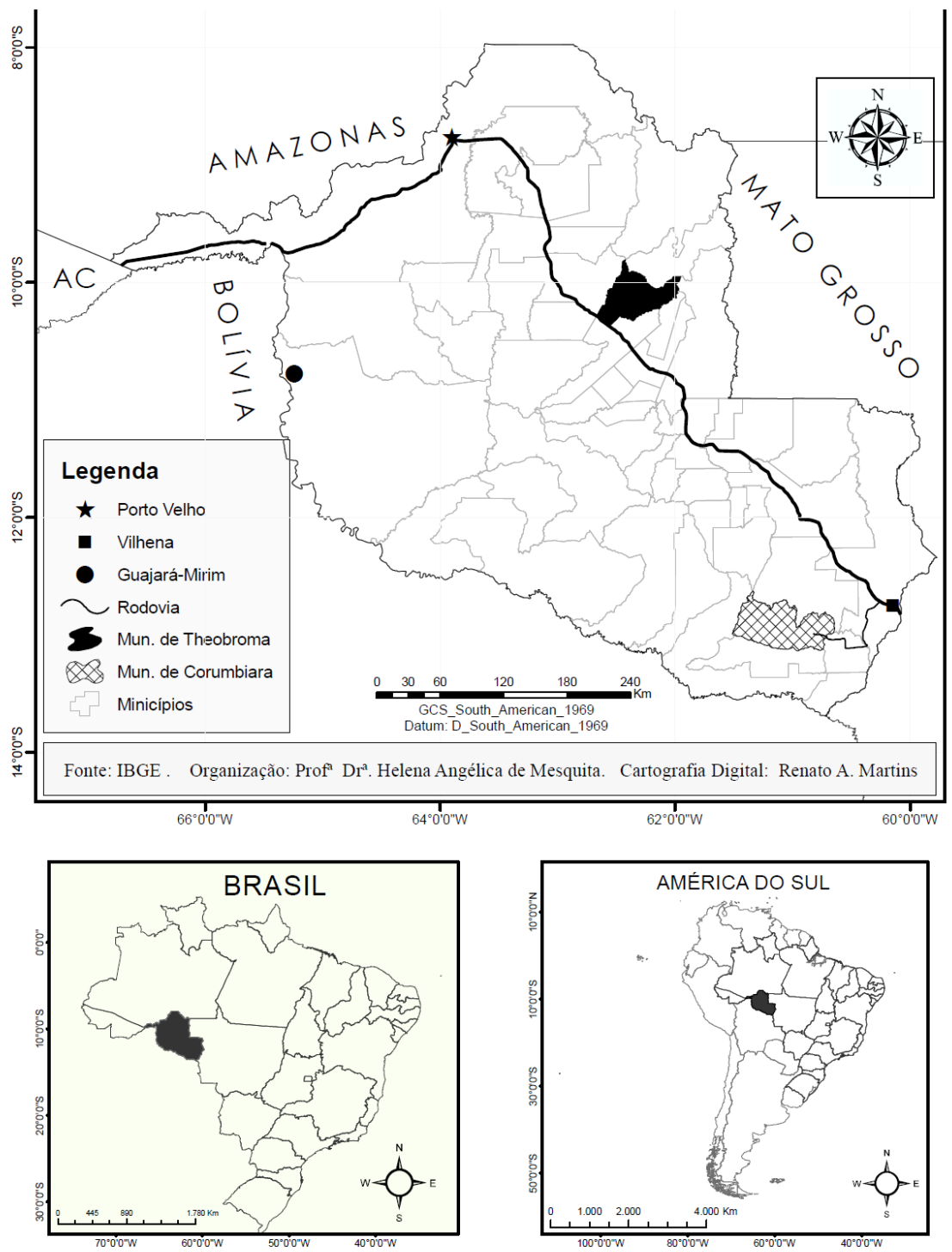

Figura 1 - Localização da Área de Estudo 


\section{O CONFLITO DA SANTA ELINAIO MASSACRE DE CORUMBIARA}

\section{O Conflito na Fazenda Santa Elina}

Do dia 14 de julho até 8 de agosto a ocupação da fazenda Santa Elina era mais um dos quatrocentos e quarenta conflitos de terra que aconteceram em 1995 no Brasil e um dos quinze que aconteceram só em Rondônia naquele ano . Portanto, pode-se concluir que no dia 14/07/95 estava começando o que foi uma tragédia anunciada: O Massacre de Corumbiara.

Em pouco tempo o acampamento já estava funcionando com as comissões, alguns coordenadores tinham sido designados antes mesmo da ocupação, enfim formaram as equipes e começaram a trabalhar e o acampamento era uma realidade. Mas uma realidade muito precária, como afirmou Sebastião Salgado .

Os acampamentos são piores que campo de refugiados, são absolutamente abandonados e são às vezes atacados, mas resistem pela esperança de possuir a terra e ter dignidade. Os menores de rua, os favelados são aqueles que desistiram de lutar para ficar na terra.

Todo dia chegavam mais famílias querendo fazer parte do acampamento. Os que chegavam deviam ser apresentados por alguém que estava no acampamento ou tinham que ter alguma referência .

Os soldados que foram levados de Porto Velho eram da COE . Eram soldados da elite da PM com treinamento especial e armamento também especial. O comandante da COE naquela ocasião era o Capitão José Hélio Cysneiro Pachá, depois promovido a Major.

Os fazendeiros articulavam tudo para varrer os posseiros do local. Os posseiros recebiam apoio dos vizinhos e de alguns políticos, especialmente, do vereador Nelinho e do Suplente de Vereador Sebastião Sobrinho .

O governador tinha conhecimento da situação da Santa Elina e não tomou nenhuma providência a fim de evitar a tragédia que já se anunciava. O Secretário de Agricultura, que era do Partido dos Trabalhadores, também tinha conhecimento da situação. Nenhum deles se manifestou sobre o caso.

Tudo indica que no caso da Santa Elina, os opressores queriam mais que um despejo, queriam uma "lição de violência", para que as ocupações cessassem na região.

A imprensa naquele dia teve papel muito importante, pois registrou em áudio e vídeo acontecimentos no acampamento e na entrada dele, conversaram com posseiros e gravaram uma longa entrevista com Cícero Pereira Leite Neto que, com muita clareza e objetividade, explicou as condições em que estavam ali, quem os apoiava, as necessidades daqueles camponeses e a firme decisão de lutar pela terra, também fez graves denúncias sobre as pressões que os posseiros da Santa Elina e até os assentados dos PAs próximos estavam sofrendo de jagunços e dos fazendeiros.

\section{O Massacre de Corumbiara}

Na madrugada do dia nove de agosto o acampamento foi cercado por todos os lados e começou o MASSACRE DE CORUMBIARA.

O acampamento foi cercado quando ainda estava muito escuro, foram usadas bombas de efeito moral, tiroteio por longas horas com armas muito pesadas, mulheres foram usadas como escudo humano pelos policiais e por jagunços. Segundo relatos, um grande número de jagunços, alguns vestidos como policiais entraram infiltrados no meio das tropas e muitos homens estavam encapuzados. O acampamento foi totalmente destruído e depois incendiado. Não sobrou nada do que os camponeses haviam levado para começar "o que seria uma vida nova". Tudo se transformou em pesadelo.

Os homens que não morreram ou não conseguiram fugir pela mata ficaram presos no campo de futebol. Os homens ficaram por longas horas sem água, sem comida, apanhando e sofrendo todo 
tipo de humilhações. As mulheres e as crianças também ficaram presas em cima de caminhões por longas horas sob um sol escaldante passando fome e sede. Os posseiros foram presos, mortos e torturados e o acampamento foi completamente destruído.

Em todas as entrevistas e conversas com os camponeses que estiveram na Santa Elina e seus vizinhos há uma coerência e coincidência nas informações ao descrever o ataque ao acampamento, a entrada dos jagunços e policiais, espancando, atirando e torturando dentro do acampamento, depois de rendidos, a continuação das torturas e execuções, a retirada dos posseiros presos no local do acampamento até o campo de futebol. Homens e meninos eram arrastados e espancados sistematicamente, foram obrigados a comer terra molhada com sangue. Além de todas as torturas físicas ainda sofreram constrangimentos morais e psicológicas e agressões verbais.

Os depoimentos dos posseiros comprovam que houve realmente um Massacre em todos os sentidos da expressão. A vida daquelas centenas de pessoas ficou à prova desde o momento que foi atirada a primeira bomba de gás dentro do acampamento até a chegada do advogado da CPT na delegacia de Colorado do Oeste, no dia 10 de agosto, ou seja, aqueles camponeses viveram mais de vinte e quatro horas de torturas ininterruptas.

Durante todo esse tempo os camponeses foram torturados porque os torturadores queriam saber quem eram os líderes e onde eles estavam. Isto equivale a dizer que aqueles que lideraram aquela ocupação já haviam sido "julgados e condenados sumariamente" por quem organizara aquela ação repressiva. Inclusive entre os acontecimentos está aquele que envolveu um agente de saúde de Corumbiara que, ao passar pela linha 155 ao lado do campo de futebol, foi preso e teve a moto destruída. Os assentados vizinhos do acampamento da Santa Elina testemunharam posseiros sendo espancados quando pediam água.

186 Os posseiros foram removidos do acampamento para o campo de futebol do PAAdriana, transformado em QG da PM e ali ficaram até o final do dia, sem comer e sem beber água. As torturas continuaram mesmo na presença da imprensa, do Prefeito de Corumbiara e do Vereador Percílio. O Prefeito e o Vereador estiveram no campo de futebol por volta de 15 a 16 horas daquele dia e viram o preso (sem-terra) Sérgio ser chutado por um policial.

Sobre o desaparecimento do Sérgio, no recurso à Pronúncia, o promotor Ivo Sherer escreveu:

É certo, efetivamente, que o major não assumiu a execução de Sérgio, até porque sua autoria direta é atribuída aos pistoleiros arregimentados pelo fazendeiro Antenor Duarte do Vale, mas não é menos certo que entregou Sérgio a estes últimos quando já estava preso e amarrado por uma corda, impossibilitado, de já, naquele momento oferecer resistência .

Homens, mulheres e crianças foram impedidos de se alimentar, de beber água e inclusive de fazer as necessidades fisiológicas, ficaram ouvindo ameaças de morte, olhando para os mortos estendidos no chão, vendo companheiro sendo retirado e jogado em veículos que se retirava e não voltava. As crianças não podiam nem chorar em voz alta. Mães tinham de colocar a mão na boca das crianças para que elas não gritassem. Outras mães, separadas de filhos; maridos separados de esposas. Era o desespero de não saber onde estava o seu ente querido, se vivo ou morto e não poder sequer perguntar. Via-se um amontoado de homens sentados quase uns sobre os outros.

O próprio Major Ventura declarou, em seu depoimento que, quando voltou do acampamento dos posseiros para o QG, depois do despejo consumado, ali estavam cerca de setecentos e cinquenta pessoas e haviam inúmeros veículos Toyota, ônibus, caminhões e estavam civis portando armamento, e estes não eram da Polícia Civil, e o Major disse ainda que viu, no acampamento, policiais pisando em cima de civis.

As mulheres e crianças foram trazidas para o QG e colocadas em caminhões e ali ficaram detidas por longas horas. Algumas pessoas serviram água, até alguns pacotes de biscoito. Segundo muitas daquelas mulheres, aqueles foram momentos muito dolorosos. O caminhão com as mulheres se 
deslocou mais cedo e, chegando em Colorado do Oeste, foram levadas para o Centro Comunitário, onde ficaram até amanhecer o dia, sob vigilância, e não puderam saber notícias de seus maridos, filhos, outros parentes ou conhecidos que estavam lá no acampamento. O depoimento de Maria, mãe da Vanessa, mostra como aquelas pessoas eram tratadas.

Ali quando chegamos no Colorado, eles pegaram a minha filha e levaram para o hospital, diz que ia para o hospital. Naquela altura eu pensava que o meu marido também estava morto. Eles me levaram para a delegacia, o Romerito junto comigo. Depois levaram nós pro centro comunitário, lá estavam as mulheres. Aí eu fiquei lá e já amanheceu o outro dia e eu não vi mais minha menina. Aí chegou alguém e avisou que iam enterrar a menina como indigente em Colorado. Eu pedi, eu gritei, eu chorei, eu queria ver a minha filha. Eles falaram que antes eu tinha que dar depoimento...

Os trezentos e cinquenta e cinco presos que estavam naquele campo foram transportados amontoados em caminhões até a cidade de Colorado do Oeste. Quando saíram do QG já estava escurecendo e o transporte foi a continuação do massacre. Os homens foram colocados uns sobre os outros dentro do caminhão e continuaram sofrendo ameaças. O posseiro Moacir Camargo já estava no caminhão quando levou um tiro que lhe traspassou o corpo. Como as estradas eram péssimas, os motoristas faziam questão de aumentar os seus sofrimentos indo em alta velocidade, dando solavancos e ferindo mais ainda aqueles corpos já tão machucados, tão famintos, sedentos, ameaçados...

Este e outros acontecimentos denotam o sofrimento daquelas pessoas e a falta de respeito por parte das autoridades. Não houve empenho em identificar os mortos e dificultavam o acesso daqueles que procuravam desaparecidos.

O Sr. Raimundo, pai do Sérgio, procurou pelo filho na Delegacia, no Ginásio de Esportes, nos hospitais e no necrotério. Ele olhava cada rosto de homem ferido e cada morto à procura do filho. Ele sabia que Sérgio estava entre os presos, o Vereador Percílio lhe dissera que o vira sendo chutado no campo de futebol por um policial. Raimundo sabia também que seu filho tinha sido retirado separadamente e antes dos outros presos.

A busca de Raimundo durou dezoito dias. Durou mais que os quinze dias que ele estivera desaparecido, porque quando o corpo foi encontrado foi enterrado às pressas como indigente. Quem avisou ao advogado José Francisco Cândido sobre o aparecimento daquele corpo e as circunstâncias do sepultamento foi a proprietária da funerária, que tinha realizado o enterro. Só depois da exumação, a busca do Sr. Raimundo acabou.

A dona da funerária confirmou o que muitas famílias já haviam me dito, que os corpos dos sete sem-terra e do H05 vieram para Vilhena e ficaram jogados no necrotério do hospital. Não foi feito esforço para a identificação e não permitiram que se fizesse velório ou se fizesse um enterro decente. Todos foram enterrados em silêncio e sem acompanhamento lança dúvida sobre a culpa de Cícero e Claudemir, afinal os dois estavam dentro do acampamento o tempo todo. Claudemir foi preso e sistematicamente torturado. O Coronel diz, com todas as letras, que os posseiros são vítimas, e coloca os policiais na mesma condição, de vítimas. Não concordo com as palavras do Coronel, mas, de certa forma, naquele campo lutavam entre si vítimas de um modelo político e econômico cujas formas de se impor são brutais. O conflito na Santa Elina foi semelhante a muitos outros que aconteceram ao longo destes quinhentos anos de ocupação capitalista do território brasileiro. $\mathrm{O}$ Massacre de Corumbiara se tornou um emblema, assim como o Massacre de Eldorado do Carajás, ocorrido nove meses após Corumbiara.

Nos dois casos, os massacres tiveram grande repercussão. Constituem marcos definitivos na longa história de luta dos trabalhadores e na longa história de repressão a eles. Marcam de forma objetiva e definitiva o pacto das elites latifundiárias no Governo Fernando Henrique Cardoso.

O que fica claro é que os assentamentos são criados para atenuar os conflitos sociais no campo, mas não são inseridos em um programa estratégico de desenvolvimento sócio-econômico. O assentamento Nova Vanessa é o exemplo acabado de que a marginalização adquire uma nova face. Essa 
realidade paulatinamente vai sendo modificada através de luta, trabalho e organização desenvolvidos.

É preciso considerar que estas pessoas perderam tudo durante o massacre da Santa Elina e tiveram que recomeçar a vida do nada. As únicas coisas que lhes restaram foi a esperança, a dignidade e a capacidade de luta. A violência contra o trabalhador vai além daquela explicitada na grande mídia quando acontecem os massacres e as mortes no "atacado e no varejo".

Quando assentado na terra, a luta recomeça, porque ficar na terra conquistada é muito difícil. Os assentados de Nova Vanessa lutam contra tantas adversidades que é difícil compreender "como" resistem, mas é fácil saber "por que" resistem. Convivendo com eles pude testemunhar que estas pessoas se negam a sucumbir a esse massacre cotidiano que se tornou suas vidas, se negam a perder a terra que já custou tantos sofrimentos, se negam a perder a dignidade, porque para eles a terra e o trabalho são a única possibilidade de vida. Eles continuam sonhando e lutando por um mundo de paz, de justiça e de fartura.

Começo este capítulo citando Dom Tomaz Balduíno, então presidente da CPT:

O caso Corumbiara é um caso bem típico porque põe o conjunto da sociedade organizada, juizes, políticos, poder executivo, poder legislativo, tudo de um lado só, do lado do latifúndio, contra a organização dos camponeses .

Dom Tomás Balduíno, profundo conhecedor da realidade brasileira, no que diz respeito à violência no campo, antecipou, com esta declaração o que seria o júri popular, no qual foram julgados os envolvidos no Massacre de Corumbiara. No julgamento, ocorrido em Porto Velho de 14 de agosto a 6 de setembro. de 2000, foi possível comprovar a veracidade de cada palavra proferida pelo então presidente da CPT. Foram condenados os sem-terra Cícero Pereira Leite e Claudemir Gilberto Ramos, mesmo sem provas nos autos, e absolvidos os oficiais que comandaram aquela ação repressiva, na qual homens foram executados sumariamente, crianças, mulheres e velhos foram torturados. Os não oficiais não só saíram livres como foram festejados como heróis, o que torna possível compreender o poder que o latifúndio ainda tem neste país e, particularmente, em Rondônia.

O julgamento em Porto Velho foi a continuação do massacre dos camponeses e, desta vez, sob os olhares de toda a sociedade, inclusive via internet. O massacre não se deu somente pela condenação dos dois sem-terra, mas também pelos discursos dos promotores e dos advogados dos policiais.

Corumbiara continuou fazendo vítimas. Em dezembro do mesmo ano, o vereador do Partido dos Trabalhadores, Manoel Ribeiro, o Nelinho, foi assassinado em emboscada preparada por pistoleiros contratados pelo vereador Percílio do PMDB. Nelinho era filho de camponeses e era muito respeitado por seu trabalho junto aos movimentos sociais, ao STR e a Igreja. Nelinho seria o candidato a prefeito de Corumbiara pelo PT; segundo correligionários e até mesmo seus adversários, tinha muita chance de ser eleito.

Para não concluir pergunto: Quantos anos serão necessários para que as pessoas, ao lerem a história do Massacre de Corumbiara, constatem que aquela aspiração era legítima, a resistência dos camponeses era justificável? Conseguirão compreender que a Justiça, hoje, no país, especialmente em Rondônia, reflete a realidade dos outros setores da sociedade? Vão perceber como o Brasil é um país onde o latifúndio ainda comanda as várias instâncias do poder? Será que serão necessários cem anos para que Cícero e Claudemir e outros lutadores, camponeses ou não, sejam reconhecidos como inocentes e vítimas do latifúndio, da corrupção e da justiça tendenciosa?

A sociedade brasileira não encontrará a paz enquanto a violência continuar impune. Nem os camponeses se calarão enquanto as elites continuarem intransigentes com relação à terra. Menos de um ano depois, outra Corumbiara aconteceu no governo social democrata (na verdade neoliberal) de FHC: Eldorado do Carajás.

A história tem mostrado que os desterrados e desterritorializados têm-se organizado e têm enfrentado esta estrutura secular de dominação e espoliação. Os camponeses têm conseguido romper 
este cerco e, de certa forma, colocar a questão em evidência e provocar a discussão na sociedade. Em certas situações, têm provocado até indignação, que por si só não resolve os problemas, mas, pelo menos, é uma forma de provar que algo está errado na condução da política brasileira em geral e em especial, das políticas agrárias.

Corumbiara confirma o que Martins diz

As lutas dos trabalhadores rurais, no Brasil, tem esbarrado, ao longo da História, com uma dificuldade estrutural sistemática. As conjunturas de abertura política e, portanto, aquelas em que os movimentos populares deveriam resultar numa ampliação da participação democrática e na conquista de um lugar político para os trabalhadores rurais e para as populações indígenas, tem sido, ao contrário, conjunturas de fortalecimento daquilo que ainda hoje, em várias regiões do país se pode chamar de oligarquias. (MARTINS, 1986, p. 71)

\section{REFERÊNCIAS BIBLIOGRÁFICAS}

ALDIGHIERI, M. Josimo: A Terra, a Vida. São Paulo: Edições Loyola, 1993.

ANDRADE, M. C. de. Agricultura \& Capitalismo. São Paulo: Livraria Editora de Ciências Humanas, 1979. BECKER, B. K. Geopolítica da Amazônia. A nova fronteira de recursos. Rio de Janeiro: Ed Zahar, 1982. BECKER, B. K. Amazônia. São Paulo: Ed. Ática, 1990.

CÂMARA DOS DEPUTADOS. Tribunal Internacional. Julgamento dos Massacres de Eldorado dos Carajás e Corumbiara. Comissão de Direitos Humanos, Centro de Documentação e Informação - Coordenação de publicações, Brasília, 1997.

CASTIEL, S. M. M. C. Raízes de Rondônia. Porto Velho, 1990.

CHAYANOV, A. V. La Organizacion de la Unidad Económica Campesina. Buenos Aires: Ed. Nueva Vision, 1994.

COSTA, E. V. da. Da Monarquia à República - Momentos Decisivos. $6^{\text {a }}$ ed. São Paulo: Ed. Brasiliense, 1994.

CPT (Comissão Pastoral da Terra). Conflitos no Campo Brasil. Goiânia. 94, 95, 96, 97, 98 e 99.

CUNHA, S. R. P. O Xadrez da Terra (Um Estudo Sobre a Colonização Dirigida em Rondônia). Dissertação de Mestrado. UFPA. Belém, 1985.

FERNANDES, B. M. A Formação do MST no Brasil. Petrópolis: Vozes, 2000.

GONÇALVES, C. W. P. Paixão da Terra - Ensaios Críticos de Ecologia e Geografia. Rio de Janeiro: Rocco /Socii, 1984.

GRZYBOWSKI, C. Caminhos e Descaminhos dos Movimentos Sociais no Campo. $2^{\mathrm{a}}$ ed. Petrópolis: Vozes/Fase, 1990.

HOBSBAWM, E. A Era do Capital 1848-1875. 4 ed. São Paulo: Paz e Terra, 1988.

IANNI, O. Ditadura e Agricultura. Rio de Janeiro: Civilização Brasileira, 1986.

IANNI, O. A Luta pela Terra. $3^{\text {a }}$ ed. Petrópolis: Vozes, 1981.

IBGE. Censo Demográfico 1991 - resultados do universo relativos às características da população e dos domicílios. Número 2 - Rondônia. Rio de Janeiro, 1991.

IBGE. Sinopse Preliminar do Censo Demográfico 1991. Número 2 - Rondônia - Acre. Rio de Janeiro, 1991. IBGE. Dados Preliminares do Censo 2000.

INCRA. A contribuição do INCRA dentro do processo de ocupação do território de Rondônia. Coordenadoria Especial do Território de Rondônia (mimeo)

INCRA. A Estrutura Fundiária de Rondônia. 1998 (mimeo).

INCRA. Dossiê (Divisão de Assentamento). Superintendência Regional de Rondônia - SR/17. Dezembro de 2000 (mimeo). 
KAUTSKY, K. A. Questão Agrária. Vol. 1 e 2. Porto: Portucalense Editora, 1972.

JORNAL FOLHA DE SÃO PAULO. 31/08/00.

JORNAL FOLHA DE SÃO PAULO. 02/01/2000.

LACOSTE, I. A Geografia - Isso serve, em primeiro lugar para fazer a guerra. Campinas: Papirus, 1988. LINHARES, M. Y. \& SILVA, F. C. T. História da Agricultura Brasileira - Combates e Controvérsias. São Paulo: Ed. Brasiliense, 1981.

LUXEMBURG, R.. A Acumulação do Capital. Vol. 1 e 2, Coleção Os Economistas. São Paulo: Nova Cultural, 1988.

MARIGHELlA, C. et alli. A Questão Agrária no Brasil. São Paulo: Ed. Brasil Debates, 1980.

MARTINE, G. \& GARCIA, R. C. Os Impactos Sociais da Modernização Agrícola. São Paulo: Ed. Caetés, 1987.

MARTINS, J. S. A Reforma Agrária e os Limites da Democracia na Nova República. São Paulo: Hucitec, 1986.

MARTINS, J. S. Os Camponeses e a Política no Brasil. (As lutas sociais no campo e o seu lugar no processo político). $3^{\mathrm{a}}$ ed. Petrópolis: Vozes, 1986.

MARTINS, J. S. O Cativeiro da Terra. $4^{a}$ ed. São Paulo: Hucitec, 1990.

MARTINS, J. S. Revisando a Questão Agrária. Boletim do Militante MST. n. 27, 1996.

MARTINS, J. S. Fronteira - A Degradação do Outro nos Confins do Humano. São Paulo: Hucitec, 1997.

MESQUITA, H. A. de. Corumbiara: O Massacre dos Camponeses. In: Anais do 8o Encuentro de Geógrafos de América Latina. Santiago, 2001.

MESQUITA, H. A. de. Corumbiara: O Massacre dos Camponeses se estende ao/no Júri. In: site www. cptnac.com.br. 2001.

MESQUITA, H. A. de. Os Meninos vão à Luta. Boletim Goiano de Geografia. v. 20 - n. ${ }^{0}$ 1,2, Jan.-Dez. 2000.

MESQUITA, H. A de. Espaço Agrário Brasileiro: exclusão e inclusão social. Boletim Goiano de Geografia - v. 28, n. 1 (2008).

MODESTO, R. G. A Contribuição do INCRA Dentro do Processo de Ocupação do Território de Rondônia. INCRA/CETR. Porto Velho, 1980. (mimeo).

OLIVEIRA FILHO, M. de. Rio Maria - A Terra da Morte Anunciada. São Paulo: Ed. Anita Garibaldi, 1991.

OliVeirA, A. U. de. A Geografia das Lutas no Campo. São Paulo: Contexto, 1996.

OLIVEIRA, A. U. de. Integrar para (não) Entregar. Políticas Públicas e Amazônia. Campinas: Papirus, 1991.

PLANAFLORO. Desmatamento nos Setores 09 e 10 da Gleba Corumbiara - 1993 até 1996. Porto Velho: Governo do Estado de Rondônia, PNUD, 1997

PERDIGÃO, F. \& BASSEGIO, L. Migrantes Amazônicos - Rondônia: A Trajetória da Ilusão. São Paulo: Edições Loyola, 1992.

PONTIFÍCIO CONSELHO. Justiça e Paz. Para uma Melhor Distribuição de Terra - O Desafio da Reforma Agrária. Cittá Del Vaticano: Libreria Editrice Vaticano, 1997. (mimeo).

SALGADO, Sebastião. PROGRAMA Jô Soares, onze e meia. Rede Globo. Reprise 05/120/97.

REFORMA AGRÁRIA. Revista de Associação brasileira de reforma agrária. n. 1, v. 25, jan., 1995.

REVISTA VEJA, 26 de abril de 2000 p. 39.

SADER, E. Quando Novos Personagens Entraram em Cena. São Paulo: Paz e Terra, 1988.

SADER, M. R. C. de T. Espaço de luta no Bico do Papagaio. Tese de Doutorado. FFLCH/USP, São Paulo, 1986. (mimeo).

SANTOS, M. Espaço e Método. São Paulo: Nobel, 1988.

SHANIN, T. La Classe Incômoda. Madrid: Alianza Editorial, 1993.

SILVA, E. I. da. A Região como Resultado de Múltiplos Processos. Boletim Goiano de Geografia. Cegraf, UFG. v. 11. n. 1. jan./ dez. 1991. 
SOJA, E. W. Geografias Pós-Modernas - A Reafirmação do Espaço na Teoria Social Crítica. Tradução: Vera Ribeiro. Rio de Janeiro: Jorge Zahar Editor, 1993.

STÉDILE, J. P. (Org.). A Reforma Agrária e a Luta do MST. Petrópolis: Vozes, 1997.

VALVERDE, O. Estudos de Geografia Agrária Brasileira. Petrópolis: Vozes, 1985.

VELHO, O. G. Capitalismo Autoritário e Campesinato. São Paulo: Difel, 1979.

VIANNA, A. e outros. Terra de Trabalho e Terra de Negócio - Estratégias de Reprodução Camponesa. Rio de Janeiro: CEDI, 1990.

VIEIRA, M. do P. de A. e outros. A Pesquisa em História. São Paulo: Ática, 1989. (Série Princípios)

WOLF, E. R. Sociedades Camponesas. Tradução de Oswaldo Caldeira C. da Silva. $2^{\mathrm{a}}$ ed. Rio de Janeiro: Zahar Editores, 1976.

WOORTMANN, E. F. \& WOORTMANN, K. O Trabalho da Terra - A Lógica e a Simbólica da Lavoura Camponesa. Brasília: Editora UNB, 1997.

Trabalho enviado em agosto de 2011 Trabalho aceito em outubro de 2011 